vroeger - van wege de Nederlandsche Phytopatologische Vereeniging belast met het geven van inlichtingen aangaande plantenziekten en schadelijke dieren. Hij versoek', tot nadere aankondiging, de te onde:zocken voorwerapen te blijven senden aan sijn adres te Wageningen

$D^{\mathbf{r}}$ J. RITZEMa Bos.

\title{
POOT DE PLANTEN MIDDEN IN DEN BLOEMPOT!
}

't Is cene zaak, oogenschijnlijk van weinig belang, waarop ik de aandacht van den lezer wensch te vestigen ; en toch is zij van meer gewicht dan het schijnt. Natuurlijk zal iedereen, die eene plant gaat verpoten, beginnen met haar midden in den pot te zetten; maar nu doet hij de aarde erin en drukt die stevig aan ; en dit werk neemt hem zoodanig in beslag, dat hij niet bemerkt, hoe hij bij deze bezigheid de plant, die hij met de linkerhand vasthondt, steeds verder van 'tmidden wegdrukt. En nu stiat de plant eenmaal in den pot; de aarde is goed aangedrukt ; men laat haar maar staan, al lijkt het niet mooi, dat zij zich te dicht naar den éénen kant toe bevindt. Men denkt dat het er voor de plant zelve niet op aan komt. Toch is dat niet zoo. Aan den eenen kant ontwikkelen zich dan in eene betrekkelijk kleine ruimte vele wortels; aan den anderen kant daarentegen weinig wortels in eene betrekkelijk groote ruimte. Waar de meeste wortels zijn, wordt het meeste water opgenomen. Giet men weinig, zoodat de eene (de breedste) helft van den pot (met de weinige wortels) niet te veel water krijgt, dan lijden de vele wortels in de andere (de smalste) helft van den pot gebrek; giet men daarentegen zoo overvloedig, dat de wortels aan den laatstbedoelden kant genoeg krijgen, dan krijgt de andere helft van den pot te veel, de openingen in den bodem blijven er te lang met water gevuld, en de wortels loopen er gevaar van in rotting over te gaan. De regel- 
matige groei en ontwikkeling der plant lijdt daaronder. Men dient dus er op te letten, dat bij scheef in den pot staande planten steeds de eene helft van de aarde meer begoten worde dan de andere. Maar dit zal men allicht gedurig vergeten. I Darom: zorgt dat ge steeds uwe planten midden in den bloempot poot; dat statat immers ook veel netter!

\section{J. Ritzema Bos.}

\section{BESTRIJDING VAN DE DENMENBASTAARDRUPSEN.}

Bistaarlpupsen zijn rupsvormige dicren, welke echter na de verpopping nirt, zooals the ware rupsen, in vlinders veranderen, mair in blalwespen, dat zijn eene soort van plomp gebouwde, trage vliesvleugelige insekten. I) bladwespen hebben geen' angel, zooals de insgelijks tot de vliesvleugeligen behoorende bijen en wespen, maitr zij hebben aan haar achterlijf eenen toestel om rieren te leggen, lie vall een zaagrormig gedeelte is von'zien, met bchulp waurvan zij eene insnijding zagen in een blat of eon ander plantendee, in welke insuijding zij ren eitje schuiven. Inat eitje neemt uit de omgevente? plantenweefsels eenig vocht op, walathor het spoedig zoodinig opzwelt, dat het stevig drukt tegen do wanten der door de bladwesp vervairdigle insuijding, en dus goul vastzit.

De bastalardrupsen, wolke zich uit het eitje ontwikkelen, gelijken zeer veel op ware rupsen, en hobben dus nok dezelfde levenswijze; zij zijn echter van de laatstgenoemlen te onderscheiden o. a. $1^{\circ}$ door haren bolvormigen kop, terwijl de kop der ware rupsen plat is, en $2^{\circ}$ loor het groote antal paren pooten aan het achterlijf, 't welk bij de ware rupsen hoogstens 5 bedraagt, bij le bastaarlrupsen 6,7 of 8 paar. Ware rupsen zoowd als bastaarlrupsen hebben irie paar gelede " borstpooten" aan het vórirlichatam of borststuk. 